\title{
Más sobre Sebastián Vázquez: nuevas obras atribuidas y estado de su producción (1766-1798)
}

Christian Peytavy Université de Pau et des Pays de l'Adour

CES.XVIII, núm. 18 (2008), págs. 81-118. 
Resumen: Desde que en Le sainete à Madrid à l'époque de don Ramón de la Cruz Mireille Coulon llamó la atención sobre este prolífico sainetista de la segunda mitad del siglo XVIII, el número de sainetes que se atribuyen a Vázquez no ha dejado de crecer para rondar hoy en día los ochenta sainetes. Como indica el título del artículo, se trata entonces de hacer un balance de las más recientes investigaciones llevadas a cabo acerca de la producción de Sebastián Vázquez: últimas atribuciones, número de sainetes identificados, análisis de su repartición en el tiempo y presentación del primer catálogo de los manuscritos de referencia, entre los cuales numerosos autógrafos que he podido identificar. Por otra parte, la evocación concreta de varios sainetes permite ilustrar algunos aspectos espectaculares, sociales, ideológicos o literarios de la escritura de Vázquez.

Palabras clave: Sebastián Vázquez. Siglo XviII. Sainete. Teatro menor. 
Unos cincuenta sainetes se atribuían a Vázquez cuando en Le sainete à Madrid à l'époque de don Ramón de la Cruz $z^{1}$ Mireille Coulon llamó la atención sobre la existencia de este exitoso sainetista de la segunda mitad del siglo XVIII. Unos años más tarde, gracias a la tan valiosa Cartelera teatral madrileña del siglo XVIII (1708-1808) $)^{2}$, ya eran nada menos que sesenta y ocho sainetes que se relacionaban con el nombre de Vázquez, estrenados entre las temporadas 1774-1775 y 1793-1794, pero no existía ningún análisis global de la producción del sainetista. Fue el objetivo de la tesis de doctorado que llevé a cabo en el 2006, bajo la dirección de Mireille Coulon: Les sainetes de Sebastián Vázquez: entre tradition et modernité (1773-1793) ${ }^{3}$.

Como era imprescindible que la base fuera fiable, traté de encontrar en la Biblioteca Histórica Municipal (BHM) y en la Biblioteca Nacional (BN), para cada obra, el autógrafo o el manuscrito que llevaba las aprobaciones de la censura poco anteriores a la fecha de estreno indicada en la Cartelera. Por si acaso, también consulté entonces los manuscritos de los sainetes todavía «anónimos» estrenados durante aquel período. Entre los ejemplares conservados en la BHM, cinco eran autógrafos de Vázquez: El cuidado de ronda en el Prado (1776), La quintaesencia de la miseria (1777), El Míralo todo en la tarde de San Blas (1778?), El modelo del nuevo peinado de París (1778) y Perico el empedrador (1787).

Convencido por razones que detallaré más adelante de que todavía quedan obras por atribuir al sainetista, últimamente he iniciado un rastreo cada vez más amplio y sistemático de los archivos de la BHM, y los primeros resultados son muy alentadores ya que cinco sainetes más son de Vázquez: El gracioso engaño del duende fingido (1777?), El señorito enamorado (1777?), La soberbia castigada y clemencia premiada (1782) — sainete que hasta ahora se atribuía con dudas a Ramón de la Cruz-, El torero caballero de Olmedo (de 1791 o 1792), y La tarde en el Prado (1798). A todo ello, hay que añadir el Sainete para presentar al público a la señora Mariana Márquez, en la primera semana de temporada de las representaciones de por la noche (1794) que Mireille Coulon ha podido atribuir al

\footnotetext{
Pau, PUP, 1993.

Toulouse, Presses Universitaires du Mirail, 1996.

Tesis sin publicar, Université de Pau et des Pays de l'Adour, décembre 2006.
} 
sainetista gracias a otro recibo encontrado recientemente al finalizar la segunda edición actualizada de la Cartelera ${ }^{4}$.

Con estos últimos hallazgos, ya son en total unos ochenta los sainetes que hoy por hoy se pueden atribuir a Sebastián Vázquez — 15 sainetes de costumbres teatrales, 15 sainetes de ambiente rural o asimilados, 48 de ambiente urbano o asimilados 5 - y el marco temporal de su producción se amplía por lo tanto hasta 1798.

En cambio, poco se sabe de los inicios del sainetista. La primera obra suya de la que tenemos un manuscrito es de 1774 (Las delicias del Canal en barcos, merienda y bailes), pero según la Cartelera, un recibo le atribuye un sainete de 1766, Los chascos. Lo más plausible es que durante el período 1766-1774 el sainetista haya ido ganando fama y que sus obras de juventud queden por identificar. En efecto, durante la temporada 1774-1775, la compañía de Manuel Martínez estrenó once o doce sainetes de Vázquez, y por razones meramente económicas, no imagina nadie que Martínez se habría atrevido a hacerlo si el sainetista hubiese sido entonces un completo desconocido: lo normal es que haya ido incorporando paulatinamente las obras del sainetista en su repertorio para asegurarse previamente de si gustaban o no al público.

También lleva a pensar lo que Vázquez cobraba por cada uno de sus sainetes. A partir de 1770, los sainetistas cobraban entre 300 y 600 reales por obra, siendo la tarifa máxima la de Ramón de la Cruz. Vázquez es el único que también llegó a alcanzar esta cantidad pero en una sola ocasión, ya que recibió 1200 reales por los dos sainetes que se estrenaron en la Navidad de $1775^{6}$. Los recibos de las compañías muestran que cobró a veces 400 reales — La entrega de sainetistas (1776), Los criados y el enfermo (1779) o Los payos de Trillo (1781)_ pero lo más habitual eran 500 reales como ocurrió por ejemplo con La vuelta del arriero y boda fingida (1776), La boda del guarda (1777), Las transformaciones graciosas del sopista Cubilete (1781), El castigo en diversión de Polonia (1782), Ceder la novia y dar dinero encima (1782), Los dos hermanos, uno glotón y otro sin memoria (1785), El tío Vigornia (1785) o Las travesuras de un barbero (1789), lo cual demuestra cierta popularidad.

4 René Andioc; Mireille Coulon, Cartelera teatral madrileña del siglo XVIII (1708-1808), segunda edición corregida y aumentada, Madrid, Investigaciones Bibliográficas sobre Autores Españoles, Fundación Universitaria Española, 2008.

5 He contado como dos sainetes El día de lotería y El chasco del sillero, aunque éste sea la segunda parte de aquél, pero son independientes como lo demuestra el hecho de que la primera parte se haya representado más veces que la segunda. En cambio, hemos contado como uno solo las dos partes de Las mujeres conjuradas, o las de Un criado ser dos a un tiempo, las cuales no se representaron por separado y no tienen sentido la una sin la otra.

6 Mireille Coulon, Le sainete à Madrid à l'époque de Don Ramón de la Cruz, Presses Universitaires de Pau, 1993, pág. 67. 
A continuación, para afinar su contextualización, presento la producción sainetesca de Vázquez por temporada teatral, de 1766-1767 a 1798-1799, con la esperanza de seguir completándola con nuevos hallazgos. En contados casos, la fecha indicada no es la del estreno sino la de la primera representación conocida. Después de cada obra, aparecen las letras C (teatro de la Cruz) o P (teatro del Príncipe) y la compañía que representó el sainete.

\section{6-1767}

Los chascos $(25 / 12)$

C: Calle

1774-1775

Las delicias del Canal en barcos, merienda y bailes (21/6)

C: Martínez

Chirivitas el yesero y Garrido ingenio (4/10)

P: Martínez

Las mujeres conjuradas (1. ${ }^{\mathrm{a}}$ y $2 .^{\mathrm{a}}$ partes) (14/11)

P: Martínez

El chasco de los cesteros y El de las manías y médicos fingidos

P: Martínez

El hambriento en Nochebuena y El sorteo de los milicianos

El soplo del contrabando y El tramposo $(30 / 1)^{7}$

P: Martínez

La pequeña folla $(16 / 2)$

P: Martínez

P: Martínez

1775-1776

Ya es gremio las majas $\left(\dot{\imath} ?^{8}\right)$

?: Martínez

Los tres novios imperfectos (7/12)

C: Martínez

Hasta aquí llegó el sainete (Riña de Polonia con Chinita) y

Lo que es del agua el agua se lo lleva (24/12)

P: Ribera

Escarmiento de estafadoras y desengaño de amadores (10/2)

P: Martínez

Sainete para la tonadilla de la cucaña (10/2)

C: Ribera

1776-1777

La entrega de sainetistas (7/4)

C: Martínez

La vuelta del arriero y boda fingida (25/5)

C: Martínez

Los buenos consejos y función de Illescas (25/8)

P: Martínez

El cuidado de ronda en el Prado (16/9)

P: Ribera

El señorito mimado $\left(\dot{¿}^{9}\right)$

?: Ribera

1777-1778

La boda del guarda (17/5)

P: Martínez

Estos dos sainetes son los únicos cuya atribución a Vázquez sigue siendo incierta.

8 Se estrenó en la temporada 1775-1776, y el manuscrito TEA 1-156-20 B de la BHM lleva aprobaciones de la censura de 1, 2 y 8 de septiembre de 1775 .

9 Sabemos que se representó en 1777 (temporada 1776-1777), y es muy probable que sea el estreno. 
El almacén de criadas y El día de lotería (6/6)

P: Martínez

El chasco del sillero $(23 / 7)$

P: Martínez

Los bribones descuidados por las mujeres chasqueados (25/8)

P: Martínez

El/ La farfulla de las mujeres y jardineros graciosos (24/9)

P: Martínez

No hay rato mejor que el de la Plaza Mayor (7/11) y

La quintaesencia de la miseria (7/11)

C: Martínez

Los cómicos indianos (7/11)

P: Ribera

Un criado ser dos a un tiempo (1. ${ }^{\mathrm{a}}$ y $2 .{ }^{\mathrm{a}}$ partes) (5/12)

C: Martínez

La casa del maestro de capilla tuerto y El gracioso engaño

del duende fingido ${ }^{10}(25 / 12)$

C: Martínez

Las campanillas y el marido viejo (30/1)

C: Martínez

El Miralo todo en la tarde de San Blas (febrero? ${ }^{11}$ )

¿?: Martínez

Los astrólogos y el boticario (18/2)

C: Martínez

Coronado dormido (24/2)

C: Martínez

1778-1779

El modelo del nuevo peinado de París (6/11)

P: Martínez

El obrador de sastres (25/12) y El degollado fingido (25/12)

P: Martínez

Los volatines fingidos y Ya llegó el tiempo preciso en que nuestro curso acabe (6/2)

P: Martínez

1779-1780

El teatro renacido $(23 / 4)$

P: Martínez

Los graciosos descontentos (7/5)

P: Martínez

Los pasajes graciosos de un lugar y El trueque de las criadas

El esquileo o los amantes descubiertos (11/6)

P: Martínez

Los criados y el enfermo (17/8)

P: Martínez

P: Martínez

Introducción jocosa para presentar a María Monteis en el teatro $(15 / 12)$

P: Ponce

1780-1781

Los matuetas andaluces $(5 / 5)$

C: Martínez

Pues que lucro no tenemos trabajando noche y día, deshagamos compañía y otro destino busquemos (13/5)

C: Martínez

El gabinete divertido de toda clase de figuras naturales (24/12) P: Martínez

10 Se trata de la primera representación conocida de este sainete, sin saber a ciencia cierta si se trata del estreno o no, aunque es muy probable.

11 El ejemplar de la BHM (TEA 1-157-8 A) lleva las aprobaciones de la censura de 26, 27 y 29 de enero de 1778. Otros (el B y el C) llevan las menciones «apestó», o «nada vale», con lo cual, sólo se representaría una vez. 
1781-1782

Los payos de Trillo (con el anteojo descúbrelo todo) (22/6) C: Palomino

El padre enfermo y la niña con amor (17/12)

C: Martínez

Las transformaciones graciosas del sopista Cubilete (25/12) P: Palomino 1782-1783

Sainete nuevo para empezar a ser graciosa la Nicolasa

$$
\text { (El sueño) (31/3) }
$$

La soberbia castigada y la clemencia premiada (3/6)

La merienda desgraciada de plumistas y criados (15/7)

Amo y criado en la casa de vinos generosos (8/11)

El castigo en diversión y petición de Polonia (8/11)

Ceder la novia y dar dinero encima (26/11)

El retorno de Francia del viajante majadero (7/12)

Las locuras más graciosas por el engaño creído (24/12)

La novia satisfecha y el novio amedrentado (2/2)

C: Martínez

C: Martínez

P: Martínez

P: Martínez

C: Ponce

C: Ponce

P: Martínez

P: Martínez

P: Martínez

1783-1784

Los embustes creídos (para empezar de graciosa la Nicolasa)

P: Martínez

1784-1785

1785-1786

El tío Vigornia el herrador (7/12)

Los dos hermanos, uno glotón y otro sin memoria (25/12)

C: Martínez

C: Martínez

1786-1787

1787-1788

Perico el empedrador (26/6)

P: Martínez

1788-1789

1789-1790

Las travesuras de un barbero $(13 / 7)$

P: Ribera

La locura más graciosa en obsequio del monarca (4/11)

P: Ribera

Paca la salada y merienda de horterillas (29/1)

P: Ribera

1790-1791

1791-1792

El torero caballero de Olmedo ${ }^{12}(14 / 2)$

C: Martínez

1792-1793

La residencia de defectos $(26 / 5)$

P: Ribera

12 Ésta es la primera representación de la que tenemos noticia y no sabemos si fue el estreno. De lo contrario, habría sido poco antes (entre el mes de agosto de 1791 y el de febrero de 1792) ya que el manuscrito TEA 1-160-14 B de la BHM lleva las censuras de 24, 28, 30 de julio, 2 y 4 de agosto de 1791. 
El marido desengañado y escarmiento de mujeres (25/12) P: Martínez 1793-1794

La locura fingida y amor logrado (boda conseguida) (18/5) P: Martínez 1794-1795

Sainete para presentar al público de Madrid

a la señora Mariana Márquez (1/7) P: Martínez

1795-1796

1796-1797

1797-1798

1798-1799

La tarde en el Prado (9/12)

P: Ramos

Además de la ya comentada laguna de los años 1766-1774, llaman la atención algunas temporadas en blanco o incluso varias seguidas (1784-1785; 1786-1787; 1788-1789; 1790-1791; 1795-1798) durante las cuales, sin embargo, es muy probable que Vázquez haya escrito sainetes. Recordemos que en estas temporadas como en las demás, se estrenaron numerosos sainetes todavía sin atribución. Es el caso, por ejemplo, de El ensayo de los juicios (1774), Ir por la lana y volver trasquilado (1774), La venta (1774), La boda impensada (1778), La industria contra miseria (1778), Los payos astutos (1778), El perlático fingido (1778), El aserrador y galanteador (1784), El calavera corregido y afortunado (1785), El maestro inglés (1786), Las figuras fingidas (1787), La diversión sin efecto (1787), Entre las chanzas las veras (1788), Lo que puede el hambre (1788), Las lavanderas del Manzanares (1788), El enfermo y convite de los vecinos (1788), La casa de las vacas (1789), La casa de recreo (1789), La tarde de Carnaval o el arroyo de san Bernardino (1792), etc. Desgraciadamente, ningún recibo los menciona y ninguno de los manuscritos que he podido consultar son autógrafos.

Recordemos por fin que el número de sainetes por temporada siempre se tiene que relacionar con el número de obras nuevas estrenadas por las compañías, aunque éste pueda evolucionar con futuras investigaciones. Por ejemplo, podrían parecer poco los 3 sainetes de Vázquez que la compañía de Manuel Martínez estrenó en la temporada 1780-1781, con respecto a los 11 de la temporada 1774-1775, pero la compañía sólo propuso 8 intermedios nuevos en aquélla contra 25 en ésta. Es que el contexto económico - la afluencia de espectadoreso teatral — la supresión del entremés antiguo por ejemplo y el desarrollo de la tonadilla — influyeron mucho en las demandas de las compañías. De hecho, a partir de los años ochenta, el número de sainetes nuevos estrenados por las compañías se ve muy reducido con respecto a los años anteriores. En 1789-1790 por 
ejemplo, en el estado actual de nuestros conocimientos, la compañía de Manuel Martínez sólo propone 6 sainetes nuevos y la de Eusebio Ribera 10.

Por otra parte, y sin que lo podamos explicar, ya que no disponemos de ningún dato biográfico sobre Vázquez, podemos comprobar que el $80 \%$ de sus sainetes fueron estrenados por la compañía de Manuel Martínez.

Las erróneas atribuciones a Ramón de la Cruz de Chirivitas el yesero (1774) y La soberbia castigada y clemencia premiada (1782), por ejemplo, demuestran lo difícil que resulta especificar lo que puede diferenciar a veces un sainete de Vázquez de uno de su homólogo madrileño porque los sainetistas podían coincidir en temas o personajes y parecerse en cuanto a estilo. Por eso, tanto en mi tesis como en un capítulo de la muy reciente Historia del teatro breve en España dirigida por Javier Huerta Calvo ${ }^{13}$, he tratado de presentar los rasgos más recurrentes de los sainetes de Vázquez, sin pretender en absoluto que fueran exclusivos del sainetista. ¿Cómo podría ser de otra forma cuando sabemos que para sobrevivir, las compañías tenían que dar al público lo que éste pedía? El mismo sainetista expresa claramente esta dependencia financiera de las compañías en varias ocasiones, como al final de Los bribones descuidados... (1777) donde quiere que los actores se despidan del público con estos explícitos versos:

$$
\begin{aligned}
& \text { Aquí da fin el sainete, } \\
& \text { todos perdonad sus yerros } \\
& \text { premiando nuestras fatigas } \\
& \text { con aplauso y con dinero. }
\end{aligned}
$$

En Introducción jocosa... (1779), hace que el barba José Espejo recuerde con nostalgia aquella edad de oro pasada en que las comedias (las de santos en particular) garantizaban buenos ingresos porque no tenían otro propósito que divertir y hacer reír al público:

$\begin{array}{ll}\text { ESPEJO } & \text { Estaba considerando } \\ & \text { en la miserable época } \\ & \text { que padecen nuestros teatros, } \\ & \text { en aquellos comediones } \\ & \text { de ángeles legos y diablos. } \\ & \text { ¡Cómo reían las gentes! } \\ \text { ¡Qué dinerales sacamos! }\end{array}$

13 Historia del teatro breve en España, Madrid-Fráncfort, eds. Iberoamericana-Vervuert, 2008. 
Es al neoclasicismo sin nombrarlo que Vázquez-Espejo atribuye esta pérdida de vitalidad del teatro cuando declara que algunos «criticones»

\author{
[...] han desustanciado \\ las tablas de carcajadas \\ tramoyas, lances y encantos $[\ldots]$
}

para sustituirlos por obras demasiado rígidas con todos los preceptos formales, cada vez más morales e «intelectuales» y que no merecen todo el trabajo que se invierte en ellas porque no corresponden a los gustos del público y suponen por lo tanto unos escasos ingresos:

ESPEJo $\quad[\ldots]$ al presente
nos las han ido llenando
de puñaladas, venenos
de tarquinadas, tiranos,
odios, comparsas, cafées,
viciosos y degollados,
con daca las unidades,
toma los númenes santos,
la acción, el verso, el preludio,
tanto heroísmo y tanto tanto
perfeccionar el asunto
y no se gana ochavo ${ }^{14}$.

Dos sainetes de costumbres teatrales, Pues ya que lucro no tenemos trabajando noche y día, deshagamos compañía y otro destino busquemos (1780) y El castigo en diversión y petición de Polonia (1782) giran también en torno a los problemas económicos de las compañías por falta de público. En el primero, muchos miembros de la compañía de Manuel Martínez deciden cambiar de oficio porque no ganan lo suficiente como para vivir, Miguel Garrido entre ellos, ya que su nuevo trabajo de chocolatero de contrabando sí

14 Además, en Los graciosos descontentos (1779), el gracioso Diego Coronado, acerca de los fragmentos de una tragedia que quiere modificar, dice que son aquellos en los que la dama «tiene aquello de llorar, / expresar la pena, el ansia, / la opresión del corazón / y otras cosas con que en Francia / lloran a moco tendido / y se ríen en España». Prueba de que, según él, la tragedia no tiene los favores del público popular, o incluso que es un género que no corresponde al temperamento español, como lo llegaba a expresar José Espejo en Introducción jocosa... (1779): «Sobre que a los españoles / sólo les gusta fandango, / y así pues fandango quieren, / darles fandango hasta hartarlos». 
[le] da de comer

y algo se pega a las tripas,

mientras que siendo actor declara:

$$
\begin{aligned}
& {[\ldots] \text { he trabajado }} \\
& \text { siete semanas cumplidas } \\
& \text { y no he ganado ni aun para } \\
& \text { cuatro cuartos de cordilla. }
\end{aligned}
$$

En el segundo, es la compañía de Juan Ponce quien decide dejar la capital en busca de un público más numeroso, y al final del sainete, Polonia tira al público varios ejemplares impresos de la petición en la que le suplica que acuda al teatro:

$$
\begin{aligned}
& \text { Polonia en nombre de esta compañía } \\
& \text { que por puntos se mira agonizando } \\
& \text { al Público suplica este día } \\
& \text { la vaya con su vista mejorando. } \\
& \text { Con lágrimas lo pide el ansia mía, } \\
& \text { amable Corte de tu piedad implorando, } \\
& \text { pues a no conseguir este deseo } \\
& \text { morimos y se cierra el coliseo. }
\end{aligned}
$$

Con lo cual, a pesar del abundante discurso teórico de los neoclásicos en la segunda mitad del siglo XVIII, las compañías y los dramaturgos siguieron proponiendo al público lo que éste reclamaba, en particular que las obras le hicieran reír y que las fuentes de distracción fueran variadas, como lo pide un emisario del patio al gracioso Miguel Garrido en Garrido ingenio (1774) al principio de la temporada teatral:

$$
\begin{array}{ll}
\text { Simón } & {[\ldots] \text { que se nos ponga este invierno }} \\
& \text { muchas comedias de teatro } \\
& \text { de aquellas que uno se ríe } \\
\text { y hay tramoyas a pasto. }
\end{array}
$$

Para satisfacer esta sed de espectáculo del público, Vázquez integró en sus sainetes todo lo que a éste le gustaba dentro del teatro o fuera de él: efectos mágicos, escaramuzas y disparos, combates amistosos con espada, graciosas 
soldadescas, fiestas de toros (corridas, encierros), espectáculos teatrales (una folla, una parodia de tragedia), fingidos volatines, diversos animales vivos o no, escenas de pánico debidas a una vaca, un oso, unos locos en libertad o fantasmas fingidos, numerosos quid pro quo o persecuciones en la oscuridad, multitud de disfraces, muy frecuentes riñas, abundancia de golpes y porrazos, así como cuantiosos bailes y cantos $^{15}$.

Los bribones descuidados por las mujeres chasqueados (1777) es una buena ilustración de este tipo de sainetes variados, dinámicos, espectaculares y divertidos, con nada menos que cinco bailes y cantos, un desfile militar y un aparatoso asalto. Las mujeres de un pueblo vagamente situado en Asturias, encabezadas por la alcaldesa (la graciosa Granadina), quieren poner remedio a la pésima situación del lugar ya que el alcalde, el escribano (los graciosos Miguel Garrido y Diego Coronado respectivamente) y los demás hombres se pasan el día en la taberna, como lo canta una criada al principio del sainete: los hombres son «muy malos bichos» porque

$$
\begin{aligned}
& \text { unos son holgazanes } \\
& \text { otros al vino dados [...] }
\end{aligned}
$$

y que

$$
\begin{aligned}
& \text { con esta plaga } \\
& \text { está el lugar perdido, } \\
& \text { gentes y casas. }
\end{aligned}
$$

Enseguida, el público puede divertirse asistiendo un buen rato a la borrachera de éstos, siendo el alcalde el más afectado, como lo subrayan sus compañeros:

nosotros algo alegrillos

pero tú estás rematado.

15 Vid. Christian Peytavy, «Música, canto y baile en los sainetes de Sebastián Vázquez (1773-1793)» en Teatro y música en España: los géneros breves en la segunda mitad del siglo XVIII, eds. Joaquín Álvarez Barrientos y Begoña Lolo, Universidad Autónoma de Madrid, Consejo Superior de Investigaciones Científicas, 2008, págs. 377-391. Sólo recordaré que más del $70 \%$ de los sainetes de Vázquez incluyen estos elementos de diversión que contribuían a la variedad y al dinamismo del espectáculo. Constatamos que los sainetes nuevos escritos a partir de los años 1783-1784 incluyen cada vez menos música, e incluso se quitan fragmentos musicales poco esenciales a la historia de los sainetes más antiguos que se vuelven a representar. En cambio, se sigue representando muy frecuentemente Los tres novios imperfectos (1775), sainete en el que tres muchachos (sordo, tartamudo o tuerto) intentan deslumbrar sucesivamente a una muchacha ofreciéndole una serenata con varios compañeros. 
Prestan a reír sus titubeos y algunos de sus comentarios que están en completo desfase con la realidad. Por ejemplo, cuando está tendido en el suelo y el regidor le dice que se levante, piensa que es su mujer y que está en su cama:

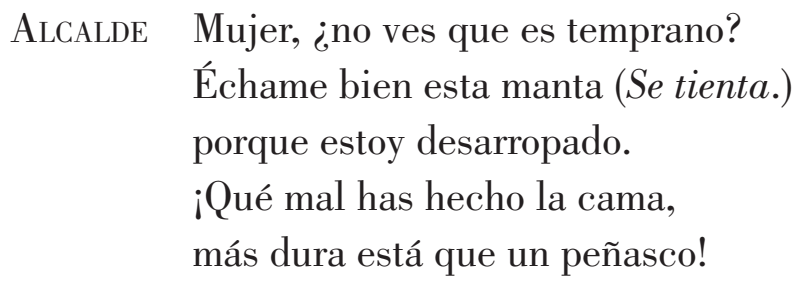

Todos manifiestan también su alegría con bailes y cantos, exóticos para los madrileños ya que en una acotación se dice que «cantan y bailan la danza prima al modo que los asturianos», exotismo ya perceptible después del reparto de los personajes donde se puede leer: «la vestimenta de todos y todas (menos el autor) ha de ser a lo asturiano». De tanto dar vueltas bailando, se derrumban todos como atontados. Ayudadas por el médico del pueblo y el autor de una compañía de la legua (Manuel Martínez), las mujeres simulan entonces una invasión mora (poco verosímil en la costa norte de España y por lo tanto más divertida), de manera que los hombres, asustados, se refugian en la taberna por ser a su juicio el lugar más seguro,

$$
\begin{aligned}
& \text { porque los moros } \\
& \text { son al vino muy contrarios } \\
& \text { y ninguno llegará } \\
& \text { apenas les dé el olfato. }
\end{aligned}
$$

Entonces, al son de clarines y timbales, empieza un imponente y divertido desfile que requiere 20 personas al menos, muchos disfraces (con algún hombre disfrazado de mujer y viceversa), caballos de pasta y un carro:

Marcha de clarines y timbales y se presenta una aparatosa salida en esta forma: primero, en tres caballitos de pasta, el médico de timbalero tocando unos timbales que vienen sobre el caballito y a sus lados otros dos de clarineros, los tres de moros con bigotes; después otros tres de moros, uno con el estandarte de las lunas y a los lados los otros dos con faroles encendidos de papel pintado como los que llevan los muchachos en el rosario; detrás de esto, Enrique, de mora ridícula, la que traerá un gran abanico cerrado y otro de moro la llevará la cola de la falda; sigue a esto de dos en dos todas las mujeres de la compañía, de moros con vestidos lucidos, bigotes, un quitasol abierto cada una y las planchas de latón para el bailete que se hará después 
siendo lo último un carro triunfal tirado de cuatro moros y en él sentada Marcela de gran turco, con bigotes largos y pipa larga y blanca fumando y a un lado el autor, de mora negra con un quitasol; dan vuelta así al tablado, para el carro a un lado, cesa la marcha y se colocan todos en buen orden.

Después de bailar un «gracioso bailete a lo moruno»e intimar a los hombres que se rindan, se lanzan al asalto de la taberna:

Sacan entre todas las mujeres una cureñita natural con su cañón de las que hay chiquitas, poniéndola en puntería a la puerta de la taberna y todos los hombres toman escalas y rodelas unos y otros fusiles.

Arman las escalas a la ventana de la taberna, prenden fuego a la mecha del cañoncito:

Sale el tiro abriéndose a él las puertas de la taberna: suena caja y clarín, suben por las escalas a ganar la ventana el médico y otros dos o tres con espada en mano y recibiendo en las rodelas las alcancías y algunos cacharros de taberna que les tirarán para defender la subida alcalde y escribano. Los demás hombres que haya abajo darán algunas descargas de fusil a la taberna haciendo entre todos un vistoso asalto como están acostumbrados.

Como este tipo de escena no es nada corriente en un sainete, este último comentario es interesante porque demuestra que en la mente del sainetista este aparatoso asalto debía recordar un fragmento de comedia militar. Todos los hombres son capturados, por supuesto, y tras un simulacro de juicio ${ }^{16}$, les vendan los ojos porque los van a degollar. Pero mientras cada uno espera su turno de rodillas, desesperado, pensando que sus compañeros ya han muerto, las mujeres se van sigilosamente. Al cabo de un rato, extrañados, los hombres se quitan las vendas y descubren que están todos sanos y salvos. Finalmente, las mujeres les cuentan la verdad, los hombres deciden enmendarse y terminan cantando y bailando una vez más la danza prima, modificando la letra para saludar cada parte del teatro.

Además del aspecto cómico y espectacular, se podría pensar que este sainete tiene algún objetivo moral no solamente porque aparentemente se valora el trabajo y se condena la ociosidad y la embriaguez, temáticas tomadas muy en

16 Son las esposas de cada uno quienes se vienen a quejar, y la tonalidad es muy chistosa. Así, cuando la mujer del sastre se queja porque su marido «sin medida le ha dado», éste se defiende diciendo: «Miente, le doy con medida / pues con la vara la casco». 
serio por las autoridades, sino también porque el médico — que no es ridículo o ignorante como lo suelen ser tradicionalmente los médicos—, está del lado de las mujeres, como si se tratara de curar al pueblo de su enfermedad, que él mismo describe a los borrachos:

$\begin{array}{ll}\text { MéDICo } & \text { Mucho } \\ & \text { me compadezco mirando } \\ & \text { a vuestras pobres mujeres } \\ & \text { maltratadas y remando, } \\ & \text { perdido el lugar sin orden, } \\ & \text { por esos suelos rodando } \\ & \text { la vara de la justicia }[. . .]\end{array}$

Sin embargo, a mi parecer, este barniz moralizador es engañoso, y como otras muchas veces, permite enseñar detalladamente un vicio en escena para el regocijo del público. Es lo que con lucidez advertía Félix Enciso en su Ensayo de un poema de la poesía (1779):

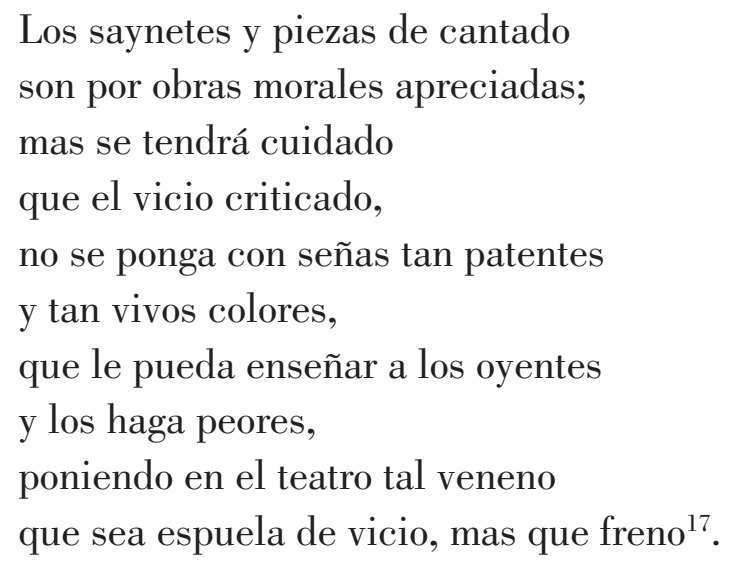

Además, lo recalca ante todo el título del sainete donde no figuran las palabras «castigados» o «escarmentados» sino «chasqueados», lo cual tiene su importancia si recordamos que otro sainete originalmente titulado El chasco de la bebida pasó a llamarse El marido desengañado y escarmiento de mujeres a petición del censor Santos Díez González, motivado por el hecho de que, según él, «de toda acción dramática se debe deducir alguna moralidad o doctrina importante» ${ }^{18}$. Asimismo, en otros sainetes, Vázquez no toma posición en contra

17 Vid. Emilio Palacios, El teatro popular español del siglo XVIII, Lleida, ed. Milenio, 1998, pág. 51.

18 Vid. el manuscrito TEA 1-157-25 B de la BHM. 
de la embriaguez. En La residencia de defectos (1792) por ejemplo, entre los muchos reproches que se le hacen a un zapatero, se dice que huelga los más días de trabajo y que todos los lunes se emborracha, con lo cual el alcalde amenaza con multarle en una peseta cada vez que esto ocurra. Algo provocativo, el zapatero le da enseguida cinco «para los días que restan / de la semana», añadiendo:

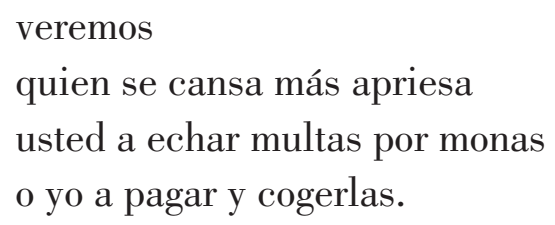

Y más adelante, mientras los otros tres personajes juzgados prometen enmendarse, el zapatero es el único quien emite reservas descaradamente pero no sin cierto humor:

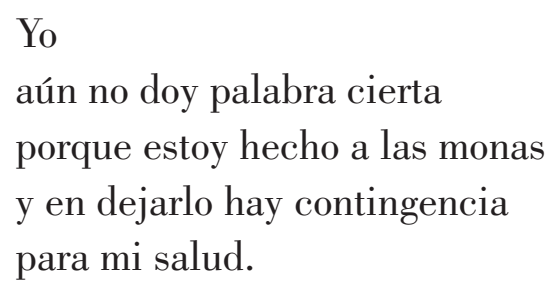

Vázquez, por lo tanto, estaba lejos de ensañarse contra los vicios populares y no era un fervoroso defensor de la moralidad, aunque se pueda percibir en varios sainetes algún que otro valor moral o educativo. Por ejemplo, como otros muchos de su tiempo, se muestra favorable a la autoridad del marido, es partidario de la libre elección de los amantes y por lo tanto está en contra de los casamientos desiguales por edad o clase social, no está muy a favor de la guerra y critica las pretensiones de las clases altas.

Aparte de los sainetes festivos y espectaculares que, como el anterior, se desarrollan en unos pueblos ficticios con una población sin rasgos específicos, están los numerosos sainetes urbanos que constituyen el verdadero universo de Vázquez. He seleccionado Las delicias del Canal en barcos, merienda y bailes (1774) no solamente porque decorado y ambiente tienden hacia el realismo y la naturalidad, sino también porque se pueden observar algunos aspectos sociológicos y espectaculares representativos de lo que encontramos en los demás sainetes suyos. En efecto, Las delicias del Canal..., que tiene lugar a orillas del Manzanares, es en cierta forma una ilustración viva de lo que Goya pintó en dos cuadros apenas posteriores, La merienda a orillas del Manzanares (1776) y Baile a orillas del Manzanares (1776-1777). Al principio se solicita la memoria y la 
imaginación del público ya que don Andrés camina evocando los encantos de este paseo y lo bonita que es la vista que se tiene desde ahí:

$$
\begin{aligned}
& \text { Don AndRÉs } \\
& \qquad . . .] \text { hay sombra, se ve el río, } \\
& \text { se divisan a lo largo } \\
& \text { las dos famosas ciudades } \\
& \text { de Carabanchel de abajo } \\
& \text { y de arriba; las murallas } \\
& \text { de Villaverde a otro lado, } \\
& \text { Leganés, y el gran Getafe, [...]. } \\
& \text { También se ve el Prado largo, } \\
& \text { a donde viene el Dios Baco, } \\
& \text { una ermita [...] }
\end{aligned}
$$

El espectador ya está condicionado cuando descubre el decorado hecho a imitación del lugar original, fácilmente reconocible gracias a su molino, su puente o sus bancos, aunque algunos detalles como los cabreros fingidos o los peces pintados parecen algo paradójicos en este conjunto que tiende hacia la verosimilitud:

Vista de la primera casa molino del Canal con el puente inmediato, pasando por él unos cabreros fingidos con sus cabras, a un lado de la casa en un palo, la tablilla de las peras y en los huecos de los lados, unos arbolillos capaces de subirse a ellos. Delante de todo el telón de la casa molino, vista marina de parte a parte para pasar los barcos a su tiempo ${ }^{19}$. Las olas serán transparentes y por detrás de ellas cruzarán varios grupos de peces. A los lados, unos asientos o bancos imitados a terrazos.

Para animar este lugar, se necesitan nada menos que 23 personajes — sin contar algunos que hacen de marineros y no hablan — y, durante toda la segunda mitad del sainete, 20 de entre ellos están en escena simultáneamente. Además, la estructura de la primera parte del sainete permite dar cierta ilusión de vida ya que el público debe imaginar que varios personajes prosiguen su paseo respectivo cuando salen de escena, hasta que la casualidad o la costumbre los lleve a todos al mismo sitio pero por caminos diferentes:

—Don Andrés encuentra a don Isidro, de camino al Manzanares.

- Cruzan un grupo de seis majas (bailando y cantando) al que tratan de acompañar hasta que llega Anastasio, el majo que está con ellas.

19 Más adelante, en efecto, «se va dejando ver un barco imitado a los del Canal, con bandera, el marinero y otros marineros remando [...]» con un grupo de majas a bordo, y se para tras recorrer la mitad de la marina. 
—Las majas encabezadas por Pepa y el majo (Anastasio) se van, diciendo que van a subir en barca.

-Don Isidro y don Andrés prosiguen su paseo.

- Se descubre el decorado del Canal.

- Sale un grupo de usías que celebran la tornaboda de doña Antonia y don Crisanto. Tras una discusión, se sientan.

—Llega un estudiante hambriento pidiendo limosna.

- Salen tres ciegos y un gallego tocando la gaita, se sientan para merendar.

-Un barco llega con las majas del principio a bordo, cruza parte de la escena mientras ellas cantan, se apean y se sientan.

-Llegan don Isidro y don Andrés, que van a saludar a una de las usías anteriores y se quedan con el grupo.

Entonces, todos se quedan ahí y cada grupo pasa sucesivamente de figurantes momentáneos a protagonistas de una o varias secuencias, más o menos largas, en las que se dedican a las actividades propias del lugar: hablan, observan a la gente a su alrededor, bailan, o meriendan. Una vez más, las fuentes de diversión son variadas: estallan varias riñas (entre doña Antonia y su marido, entre Pepa y Anastasio), el estudiante hambriento chasquea a los ciegos quitándoles su merienda en una escena que recuerda los embustes del Lazarillo de Tormes con su primer amo, las majas bailan y cantan tres veces, las usías una, y para acabar el sainete irrumpe una vaca encolerizada «bien imitada» que siembra el pánico y ofrece, como dice Vázquez en una acotación, «un rato de bulla y diversión». En efecto, la variedad de los personajes presentes ofrece muchos juegos escénicos, empezando por las reacciones contrastadas de cada uno: el gallego trepa a un árbol, los petimetres y las petimetras se desmayan, los ciegos se defienden a palos, mientras tratan de capearla «Anastasio con la capa, el estudiante con el manteo, Pepa con el delantal, y las demás [majas] con los pañuelos». Es un momento muy animado no sólo porque se oyen gritos, silbidos y advertencias de unos y otros sino también por la buena ocupación del espacio escénico: los improvisados toreros van y vienen sin cesar, al igual que la vaca cuyo comportamiento se cuida particularmente para mayor realismo: «echa a rodar la angarilla, botellas, platos, y lo demás», por supuesto embiste contra todos y llega también «alguna vez a olfatear a los desmayados». Tras herir a Pepa termina yéndose, pero este final no es nada dramático gracias a los gritos exagerados de Pepa que desdramatizan por completo la herida

¡Me ha abierto un agujerazo

tan grande que puede entrar

un coche con seis caballos!, 
lo cual debía mover el público más a risa que a compasión ${ }^{20}$.

En este sainete, el estudio sociológico es particularmente revelador de las preferencias de Vázquez, de su «sensibilidad afectiva» gracias a la fuerte contraposición entre majas y usías.

Las usías, visten «todos muy usías, como de campo», y la que destaca es doña Antonia por el enfado que se lleva porque don Crisanto, su marido, le ha dado un disgusto el día de su tornaboda. Sin embargo, no es debido exclusivamente a su carácter sino también a un sabio cálculo, como lo explica a sus amigas:
a los principios
es menester amansarlos
a los maridos, que luego
no hay modo de enderezarlos.

Fuera de este arrebato, no es particularmente risible y sus amigas tampoco, aunque se desmayen al final ante la vaca. Incluso podríamos decir que se muestran razonables cuando tratan de tranquilizar a su amiga («Sosiégate y ten cordura») o cuando ésta amenaza con arañarse:

si tienes en ello gusto

ya puedes ir empezando,

y no son altivas o pretenciosas con los demás personajes. Por fín, otra manifestación identitaria del grupo es el «minué muy piano» que se ponen a bailar.

En cuanto a las majas, llevan «zagalejos de cotón, jubones sueltos, moños con lazos, muy chuscas todas, y con panderos tocándolos y cantando al estilo de los barrios bajos», siendo su bulliciosa alegría otra característica suya. Entre ellas, destaca Pepa quien hace alarde de su majeza: tuerce el hocico, se pasea a lo chusco, fuma tabaco, escupe al suelo y no se deja intimidar por Anastasio, el único representante masculino de la majeza, con quien discute. Es que las majas sienten un profundo orgullo de ser lo que son y se mofan de todo lo que

20 Este tipo de diversiones es frecuente en los sainetes de Vázquez. En Los buenos consejos y función de Illescas (1776) se organiza una lograda corrida en la que interviene el famoso Romero en persona para lidiar. Unos payos se divierten con un ternerillo enmaromado (¡vivo!) en Las locuras más graciosas por el engaño creído (1782), capean un novillo en un sainete casi idéntico, La locura más graciosa en obsequio del monarca (1789), y otra animada corrida tiene lugar al final de El torero caballero de Olmedo (1791). Por otra parte, el pánico generado por la vaca en Las delicias del Canal se puede asemejar al causado por unos locos armados en Los pasajes graciosos de un lugar (1781) o por un oso enfurecido en La residencia de defectos (1792). 
no forma parte de su cultura. Por ejemplo, miran riéndose a las usías que bailan y hacen burla de ellas: Blasa hace comentarios irónicos,

Mira qué figuras,

qué cabriolas y qué garbo,

a las cigüeñas parecen

cuando vienen aleteando,

mientras Pepa no sólo «baila sola minuet ridículamente remedando a los seis que lo bailan» sino que exclama, mucho más radical en sus juicios:

¡Y qué rechochinería
de baile! Fuera ese asco,
que me va viniendo gana
de al minué repisotearlo.

Poco después, las majas se ponen a bailar un fandango «con castañuelas muy a lo chusco» como para demostrar la superioridad del majismo, ya que dicen:

en competencia

del minué vaya un fandango

entre las dos de chupete.

Su baile, su contoneo, el taconeado de Pepa, subyugan a todos y doña Antonia incluso no parece insensible a la majeza. Declara acerca de Pepa:

la tal moza es de anda fuera

pero festiva en su trato,

y añade que

la gente de este cacho

sabe vivir, y el que vive

se mantiene siempre sano.

Por todo ello, comprobamos así la inclinación del sainetista por las majas, por ser majas y por ser mujeres, como lo deja pensar la representación mucho menor de sus homólogos masculinos y los papeles que a éstos se les atribuye en este sainete y en los demás. Por otra parte, el hecho de que el majo convide 
cortésmente a todos los presentes (usías incluídas) a la opípara merienda que ha encargado demuestra que a pesar de la viveza de algunos comentarios de las majas, Vázquez no quería presentar relaciones conflictivas entre los dos grupos sociales. En los demás sainetes, tampoco es el caso, ya que la única vez en que un majo apalea brevemente a dos usías es en Chirivitas el yesero (1774), tras un atropello casual en la calle. En Las delicias del Canal, las usías tan sólo servían de contrapunto a las majas para poner a éstas de relieve, y de hecho, constatamos que es la única vez en los 80 sainetes estudiados que se baila minué en un sainete de Vázquez.

En efecto, la vida de las clases acomodadas no interesa a Vázquez ya que no ha dedicado ningún sainete a sus fiestas mundanas, al contrario de Ramón de la Cruz en el mismo período ${ }^{21}$. Por otra parte, a partir de los años 1770, en los sainetes de Cruz, se critica sobre todo a los petimetres por su papel de cortejo. En los sainetes de Vázquez, ningún petimetre es cortejo ni sigue a una dama desde que se levanta hasta que se acuesta para satisfacer servilmente todos sus caprichos ${ }^{22}$. Apenas si aparecen fugazmente algunos petimetres cortejos en unos pocos sainetes como El cuidado de ronda en el Prado (1776), Los matuetas andaluces (1780) o Los payos de Trillo (1781). Sin embargo, Vázquez sí critica el fenómeno de los cortejos pero sin que sea propio de la petimetría. En efecto, si una usía tiene algunos cortejos, suelen ser abates, oficiales militares, médicos y cirujanos, y notamos que las majas también tienen los suyos: en Escarmiento de estafadoras y desengaño de amadores (1776), unas majas que pretenden mejorar su situación explotan a un indiano, un repostero y un carnicero majo, y en La boda del guarda (1777), un majo echa fuera de su casa el día de su boda a un abate y un oficial militar que pretendían ser los cortejos de su mujer, la cual sin embargo, no se parece mucho a una maja.

Los escasos petimetres que aparecen, como don Isidro y don Andrés en Las delicias del Canal..., suelen estar en busca de aventuras amorosas con unas majas. En cuanto a las petimetras, algo más numerosas, se suelen caracterizar por su mal carácter y las difíciles relaciones que llevan con sus criados y marido. No aparece ninguna que se pase el día cuidando de su forma de vestir, de su peinado o de sus zapatos, o hable un castellano salpicado de galicismos.

21 Ramón de la Cruz escribe por ejemplo Las damas apuradas (1775), La tertulia de moda (1775), La academia de música (1776), El baile de repente (1777), El forastero prudente (1780), La tertulia discreta (1783), El baile sin mescolanza (1783) o El sombrerito (1785). Además, Mireille Coulon explica que cerca del $17 \%$ de los 340 sainetes de Cruz que estudió presentan a estos personajes que organizan meriendas, cenas, o saraos, porcentaje que aumenta considerablemente (el 38\%) si sólo consideramos los que Ramón de la Cruz seleccionó para los diez volúmenes de su Teatro (18 de 47). Vid. Le sainete à Madrid, op. cit., págs. 451-452.

22 Se puede ver la descripción de la vida diaria de un cortejo hecha por José Clavijo y Fajardo, en Costumbristas españoles, autores correspondientes al siglo XVIII, Madrid, Aguilar, 1950, págs. 456-460. 
Por lo tanto, la crítica de estos personajes sobre estos mismos aspectos se hace de manera más bien puntual. En Los pasajes graciosos de un lugar (1779) por ejemplo, un loco que ve pasar a una usía en un pueblo dice a su compañero:

$$
\begin{aligned}
& {[\ldots] \text { la abulta el pelo }} \\
& \text { más que una cama colgada, }
\end{aligned}
$$

o cuando estalla un incendio en El chasco del sillero (1777), entre los varios personajes que cruzan la escena corriendo y asustados está una usía que lleva un perrito faldero y sólo pronuncia dos versos:

$$
\begin{aligned}
& \text { En librando a mi perrito } \\
& \text { mas que se quemen los trastos. }
\end{aligned}
$$

Lo que sí es frecuente, aunque sea de forma puntual dentro de varios sainetes, es la crítica de los enormes e inútiles gastos que el tren de vida y las pretensiones de las clases acomodadas suponían, cuando no eran abisales «trampas» que las llevaban a la ruina. En El cuidado de ronda en el Prado (1776), se dice de una usía «que cuanto lleva debe», lo que la dama asume añadiendo que es habitual en este siglo y que

$$
\begin{aligned}
& \text { si los que vestidos van, } \\
& \text { en este lugar, de trampas, } \\
& \text { se les fueran los vestidos } \\
& \text { por el aire, se quedaran } \\
& \text { innumerables personas } \\
& \text { lo propio que Mariblanca, }
\end{aligned}
$$

una de las representaciones de Venus muy ligeramente vestida.

Por eso me parece oportuno evocar el único sainete de Vázquez enteramente dedicado a la crítica de la moda, El modelo del nuevo peinado de París (1778). Ante todo, es interesante porque el sainetista elige un punto de vista original que le permite prescindir de personajes de las clases altas, un poco en la misma óptica que Torres Villarroel en la ficción en la que veía con temor que medraban sastres, peluqueros y zapateros y que se iban a convertir en personajes influyentes ${ }^{23}$. En efecto, Vázquez muestra cómo un peluquero llamado

${ }^{23}$ Escribía: «Estos — le dije a don Francisco— son algunos oficiales de las artes mecánicas, sastres, zapateros, y peluqueros, que son los hombres ricos de este siglo [...]. Esta abundancia ha hecho ricos a los 
Coquin, «con figura afrancesada» y peinado ridículo, y una escofietera «vestida a la extranjera» llamada madama Veroniqueta, han visto su fama, su fortuna y su condición social aumentar sustancialmente gracias al afán por la moda de las clases acomodadas y de la nobleza. Con su riqueza, aumenta también su vanidad en extremo, y madama Veroniqueta, por ejemplo, no se digna a ir a casa de sus clientes si no le mandan una silla de manos para llevarla. Da lugar a una primera escena inverosímil y burlesca ya que la escofietera lleva un peinado tan alto y angosto «a modo de frontispicio de granadero y remate en punta» que deben abrir el cielo de la silla de manos para que pueda subir en ella, con el peinado y las plumas asomando por encima. Más adelante, se reúne un verdadero cónclave de peluqueros y escofieteras al que presentan el nuevo peinado que piensan poner de moda, llamado «la rueda del pavo», y su escofieta, «el alumbrado»:

Sale el Modelo de París vestido de Francesa muy decente con tontillo, mucho tacón y lo más visible de todo un anchísimo y alto peinado muy extraño y a correspondencia una escofieta grandísima colocada en ella en el modo más posible algunas luces de cabos delgados.

Para aumentar lo monumental del peinado y lo ridículo de la situación, uno de los peluqueros saca un anteojo de larga vista para observar todos los detalles, y otro se sube a una escala para averiguar con una plomada que el «edificio» esté recto. Todos tratan de hablar con mucha seriedad de la geometría y de la simetría del conjunto, pero ciertos comentarios hacen reír, en particular cuando se deja entender que todo eso es muy inestable e incluso peligroso: uno dice que si el peinado está un poco torcido es que un moscón se ha posado en él, y otro está seguro de que si se derrumba, los que están alrededor morirán bajo los «escombros». Vázquez demuestra así que la estupidez y la vanidad no tienen límites, ya que por muy pesado y ridículo que sea el peinado, siempre habrá gente dispuesta a llevarlo para distinguirse, y gente para sacarles el dinero, como lo reconoce abiertamente Luis, el inventor del peinado:

$$
\begin{aligned}
& \text { mi intención es que ganéis } \\
& \text { fama y oro divulgando } \\
& \text { su idea a las petimetras } \\
& \text { que anhelan sólo a llenarnos }
\end{aligned}
$$

\footnotetext{
sastres, y son hombres que labran casas, fundan mayorazgos y capellanías y erigen sepulcros, y mañana se han de levantar con la república, y han de ser consejeros, privados, ministros [...]», en Costumbristas españoles, autores correspondientes al siglo XVIII, op. cit., t. I, pág. 423.)
} 
de bienes y a sus maridos

a dejarlos sin un cuarto.

Los nobles, por su parte, son todavía más escasos que los petimetres y las petimetras. Van esparcidos en varios sainetes en medio de personajes más populares, aunque algunos de ellos estén acompañados de su mujer, marido o hijo (papel desempeñado por un adulto). Tan sólo he contabilizado dos vizcondes, el uno derrochador y vanidoso en El hambriento en Nochebuena (1774) y el otro extremadamente tacaño en La quintaesencia de la miseria (1777), dos marqueses enamorados de unas mujeres de clase social inferior en La farfulla de las mujeres y jardineros graciosos (1777) y El esquileo o los amantes descubiertos (1779), otro apático y pobre en Los cómicos indianos (1777), y una baronesa tiránica y con mal carácter en La soberbia castigada... (1781).

Por lo tanto, en los sainetes urbanos, los verdaderos protagonistas son los abundantes personajes populares, cuyo temperamento depende de la historia y de los actores que los encarnaban y se definen a menudo exclusivamente por sus relaciones familiares, organizadas en torno a uno de ellos que sí tiene alguna caracterización social suplementaria (sastres, zapateros, yeseros, herradores, botilleros, bodegueros, criados, soldados, ciegos, majas, etc.), como lo recalcan por ejemplo estos títulos: Chirivitas el yesero (1774), El chasco de los cesteros (1774), La boda del guarda (1777), El almacén de criadas (1777), El obrador de sastres (1778), El tío Vigornia el herrador (1785), etc.

Todos estos personajes suelen estar involucrados en historias que giran a menudo en torno al amor o a la manera de conseguir dinero o comida. En efecto, por una parte, numerosos son los sainetes que cuentan cómo un joven consigue casarse con la muchacha a la que quiere a pesar del padre o del tutor, mediante engaños, disfraces o efectos mágicos (Las travesuras de un barbero, Los astrólogos y el boticario, El chasco de los cesteros, Ceder la novia y dar dinero encima, El degollado fingido, El de las manías y médicos fingidos, El padre enfermo y la niña con amor, etc.), y abundan los personajes que buscan relaciones amorosas lícitas o no.

Por otra parte, hay una verdadera y generalizada picaresca, de manera que numerosos son los personajes (los criados en cabeza) que se dedican a sisar dinero o comida a aquellos que los tienen: por ejemplo, en El hambriento en Nochebuena (1774) es un abate hambriento quien se hace invitar a la mesa de un vizconde y roba la cena de Navidad, mientras que en Un criado ser dos a un tiempo (1777) es un criado quien quiere tener dos amos para ganar y comer doble; en La merienda desgraciada de plumistas y criados (1782), unos criados y criadas aprovechan la ausencia de sus amos par organizar una gran merienda con lo que han robado de la mesa o de la despensa, y en Paca la salada y merienda de horte- 
rillas (1790) unos criados se juntan para tener una opulenta comida en un mesón con el dinero que han sisado a lo largo de la semana a sus amos respectivos.

Pero Vázquez, como los demás sainetistas, no sólo se inspiraba de estas temáticas de larga tradición literaria o de algunos aspectos sociales de su tiempo: cualquier acontecimiento podía dar lugar a un sainete. Por ejemplo, las reformas del sistema de reclutamiento dieron lugar a El sorteo de los milicianos (1774), la coronación de Carlos IV a Las locuras más graciosas en obsequio del monarca (1789), el eclipse del 24 de junio de 1778 al principio de Los astrólogos y el boticario (1778), la llegada de una nueva actriz a Las mujeres conjuradas (1774) o a Introducción jocosa para presentar a María Monteis en el teatro (1779), y el cambio de graciosa en una compañía a Sainete nuevo para empezar a ser graciosa la Nicolasa (1782) y Los embustes creídos (1783).

El gabinete divertido de toda clase de figuras naturales (1780) también está inspirado en parte de la realidad y presenta además una estructura y aspectos metateatrales interesantes. A medio camino entre un sainete tradicional y un sainete de costumbres teatrales, empieza con el encuentro casual en el barrio de Lavapiés de Tadeo Palomino, Vicente Galván, Manuel Martínez, su hija Francisca, su yerno Francisco Ramos, Nicolasa Palomera y María del Rosario Fernández (la Tirana) que quieren ver el famoso gabinete del título. Por lo tanto, el sainete presenta una situación banal de la vida de los actores que salen a divertirse entre amigos o en familia, y son ellos quienen van a constituir el público del espectáculo, dándole más verosimilitud que si fueran personajes ficticios. Lo mismo pasa entonces con los personajes con los que se relacionan: un cobrador, dos soldados que tratan de evitar los empujones a la entrada del gabinete, o el Extranjero, el organizador del espectáculo.

Este gabinete es una especie de zoo humano en el que un extranjero presenta los «especímenes» madrileños más destacados: originalmente eran (en este orden) una maja, tres ciegos, un herrador borracho y una petimetra gigantona (los cuales representan perfectamente la sociología de los sainetes de Vázquez), pero se ve que el sainetista ha quitado la intervención de la petimetra — su nombre además está tachado en el reparto_ - para sustituirla por la de un cojo y manco, descrito en esta acotación:

$[\ldots]$ se verá [...] el manco y cojo que anda haciendo los juegos de manos por calles y plazas en la figura y vestimenta que anda [...] (y si le quieren ver, todos los días está en la plazuela de Santo Domingo con un titilimundi).

Estos comentarios ante todo muestran claramente esta inspiración directa en la realidad, ya que este personaje existió, y por otra parte, la referencia al 
titilimundi no es anodina porque el gabinete funciona sobre el mismo modelo. Un titilimundi (tutilimundi o totilimundi) es, según el Diccionario de Autoridades de 1734,

cierta arca en forma de escaparate que traen a cuestas los Saboyardos, la cual se abre en tres partes, y dentro se ven figurillas de madera movibles, y metiendo por detrás una llave en un agujero [...] hace que las figurillas anden alrededor, mientras él canta una cancioncilla [...].

Y en el gabinete, una tras otra, las figuras aparecen inmóviles cuando se levanta el telón, antes de animarse. Por ejemplo, cuando va a ser el turno de la maja, se dice: "Córrese la cortina y se descubre inmóvil y en jarras y postura garbosa doña Marica muy a lo majota decorosa ${ }^{24} »$. Y tras unos versos del extranjero, «deja [...] lo inmóvil y sale fuera haciendo de majota».

La mise en abîme final es vertiginosa, porque además de hacer coincidir en un mismo nivel de realidad público real, público simulado, personajes de ficción y figuras del gabinete, tras el espectáculo, Manuel Martínez propone veinte pesos al día al Extranjero para presentar sus figuras en el teatro. $\mathrm{O}$ sea que como el autor dice que quiere incluirlas al día siguiente, es como si los espectadores hubieran asistido a la génesis del espectáculo, es decir, cómo Martínez encontró y eligió las figuras.

Y no es la primera vez que Vázquez juega con los planos de realidad. Al principio de Hasta aquí llegó el sainete (1775), Vázquez engaña momentáneamente al público porque todo empieza como si fuera un sainete de ambiente rural habitual: unos pastores y pastoras están cantando alegres, pero, de repente, los gritos procedentes de una riña entre bastidores interrumpen lo que en realidad era una representación: el público real pasa de la ficción teatral a la «realidad», que no es sino otra ficción hábilmente disfrazada, la del sainete de costumbres teatrales al que asisten.

Además de inspirarse en las tramas tradicionales o de la actualidad de la gente en su sentido más amplio, no hay que olvidar que algunos sainetes no son realmente creaciones propias sino adaptaciones de otras obras existentes. Vázquez no sabía francés, así que a la diferencia de De la Cruz, no pudo inspirarse en las obras francesas. En cambio, convendría buscar entre las obras italianas, ya que por ejemplo Un criado ser dos a un tiempo (1777) resulta ser una composición inspirada en una

$24 \quad$ El hecho de que la maja se llame doña Marica puede sorprender, pero ella misma lo justifica cuando se lo pregunta Palomino, diciendo que hoy en día cualquiera lo lleva y que ella no quiere ser menos que los demás: «van tan baratos los dones / que lo tiene un buñuelero». 
comedia de Goldoni ${ }^{25}$. Y no me parece descabellado pensar que La quintaesencia de la miseria (1777), que es una síntesis de los fragmentos más cómicos de L'Avare de Molière, sea una adaptación de una refundición italiana de la obra francesa.

Además, sin que se pueda establecer ningún parentesco tan claro, en otros varios sainetes se pueden percibir ecos (por llamarlos de alguna manera) de la literatura anterior y del Siglo de Oro, como la escena que ya evoqué en la cual el estudiante hambriento roba la comida de los ciegos en Las delicias del Canal (1774). En El padre enfermo y la niña con amor (1781), Diego declara su amor a Isabel a la manera de Salicio en la Égloga II de Garcilaso de la Vega (aunque, repito, no sea ésta la fuente directa), sólo que, en vez de pedir a Isabel que vaya a ver las aguas cristalinas para contemplar la cara de la que ama, le presenta un espejo (vv. 550-585). Lo chistoso es que a pesar de todo, cuando la muchacha —algo corta de luces- se ve, no lo entiende.

En El torero caballero de Olmedo (1792), don Ginesio y su criado presentan cierto parecido con don Quijote y Sancho, como éste incluso reconoce:
Tomaré el caballo y vamos
a deshacer este entuerto
siendo mi amo don Quijote
y yo Sancho su escudero.

Es que como don Quijote, don Ginesio ve y recrea la realidad a través del prisma del ideal caballeresco. Afirma ser capaz de torear porque

$$
\begin{aligned}
& \text { basta saber que soy } \\
& \text { el caballero de Olmedo } \\
& \text { para salir y torear, } \\
& \text { si se ofrece, al mundo entero }
\end{aligned}
$$

habla de su borrico como si fuera un caballo excepcional:

$$
\text { «es un animal muy bello» }
$$

o

$$
\begin{aligned}
& \text { «no vino de Andalucía } \\
& \text { un animal más perfecto», }
\end{aligned}
$$

\footnotetext{
25 Antonietta CaLderone, «Gli adattamenti settecenteschi in Spagna de Il servitore di due padroni», en La festa ispanica, ed. G. B. De Cesare, Napoli, Istituto Orientale, 1994, págs. 317-343.
} 
jura no dormir ni divertirse hasta que haya librado a una mujer a la que no conocía unos minutos antes y quien le ha prometido su mano si la libraba de las garras de su padre. Movido por su ideal de justica, no teme los obstáculos que puedan surgir:

\author{
vamos a dar libertad \\ a pesar de impedimentos \\ a mi señora la Hidalga \\ doña Ciriaca de Cienfuegos,
}

la cual además viste de «hidalga a lo antiguo».

En El gracioso engaño del duende fingido (1777?) y en La soberbia castigada y clemencia premiada (1782) hay rasgos de inspiración calderoniana de La dama duende o de La vida es sueño, respectivamente, obras muy representadas a lo largo de la segunda mitad del siglo ${ }^{26}$. En el primero, como el hermano de Rufina cree que hay un duende en un cuarto de la casa, ésta no quiere desengañarle para divertirse a expensas suyas. Para ello, se valdrá con sus cómplices de un pasadizo secreto que hay dentro de un armario y que permite pasar de una habitación a otra. En el segundo, gracias a los poderes mágicos de un peregrino, se invierten momentáneamente los papeles de una zapatera y de una soberbia baronesa, la cual pronto se enmienda y se amansa frente a la autoridad y a los golpes del zapatero que no está dispuesto a tolerar la actitud de su «mujer».

Pero éstos no son más que algunos ejemplos, y sería interesante profundizar en este tipo de ejes transversales para poner de relieve la vitalidad o la frecuencia de tal o cual «motivo literario», o incluso en algunos casos, la corriente que tal idea o trama siguió por Europa, como lo hizo Francisco Lafarga con las traducciones.

A continuación, y para terminar, propongo un catálogo de los sainetes de Vázquez con las referencias de los manuscritos que llamo «de referencia», sea porque son autógrafos, sea porque llevan las aprobaciones de la censura, o en escasos casos, porque son los más fiables de entre los que existen. Para las referencias de otros manuscritos posteriores o impresos, véase por ejemplo el Catálogo de entremeses y sainetes del siglo XVIII de Juan F. Fernández Gómez ${ }^{27}$.

1. El almacén de criadas 6/6/1777, Martínez, Príncipe

26 La vida es sueño se representó quince veces de 1766 a 1795 y La dama duende, 25 veces de 1766 a 1799.

27 Universidad de Oviedo, Instituto Feijoo de Estudios del Siglo XVIII, 1993. 
BHM TEA 1-151-33, A y D

(A: autógrafo; D: censuras de 1777)

7 representaciones más de 1778 a 1794

2. Amo y criado en la casa de vinos generosos

8/11/1782, Martínez, Príncipe

BHM TEA 1-151-31 C (censuras de 1782)

17 representaciones más de 1783 a 1808

3. Los astrólogos y el boticario

18/02/1778, Martínez, Cruz

BHM TEA 1-151-9 C y D

(C: censuras de 1778; D: autógrafo)

Ningún rastro de otra representación

4. La boda del guarda

17/05/1777, Martínez, Príncipe

BHM TEA 1-152-40 A y D

(A: autógrafo; D: censuras de 1777)

7 representaciones más de 1780 a 1798

5. Los bribones descuidados por las mujeres chasqueados

25/08/1777, Martínez, Príncipe

BHM TEA 1-152-45 (autógrafo con reparto)

Ningún rastro de otra representación

6. Los buenos consejos y función de Illescas

29/07/1776, Martínez, Príncipe

BHM TEA 1-155-24 C (autógrafo)

BNN 14 602-35 b (censuras de 1776)

Ningún rastro de otra representación

7. Las campanillas y el marido viejo

30/1/1778, Martínez, Cruz

BHM TEA 1-153-5 A y B

(A: autógrafo; B: censuras de 1778)

Ningún rastro de otra representación

8. La casa del maestro de capilla tuerto

25/12/1777, Martínez, Cruz

BHM TEA 1-153-6 A y B

(A: censuras de 1777; B: autógrafo)

2 representaciones más (1787 y 1798)

9. El castigo en diversión y petición de Polonia

08/11/ 1782, Ponce, Cruz

BHM TEA 1-154-29 (autógrafo) 
BNN $14603^{16}$ (censuras de 1782)

Ningún rastro de otra representación

10. Ceder la novia y dar dinero encima ${ }^{28}$

26/11/ 1782, Ponce, Cruz

BHM TEA 1-163-8 A (censuras de 1779)

Ningún rastro de otra representación

11. Los cómicos indiano

7/11/1777, Ribera, Príncipe

BHM TEA 1-162-45 A y C

(A: censuras de 1777; C: autógrafo)

2 representaciones más (1782 y 1788)

12. Coronado dormido

24/02/1778, Martínez, Cruz

BHM TEA 1-153-33 B (autógrafo)

Ningún rastro de otra representación

13. Los criados y el enfermo

17/08/1779, Martínez, Príncipe

BHM TEA 1-163-24, impreso, Madrid, $1791^{29}$

20 representaciones más de 1780 a 1806

14. El cuidado de ronda en el Prado

16/09/ 1776, Ribera, Príncipe

BHM TEA 1-162-44 B y C

(B: censuras de 1776; C: autógrafo)

Ningún rastro de otra representación

15. El chasco de los cesteros (o el sacristán mago)

5/12/1774, Martínez, Príncipe

BHM TEA 1-154-26 $6^{30}$

4 representaciones más de 1786 a 1807

16. El chasco del sillero (2. ${ }^{\text {a }}$ parte de El día de lotería)

23/07/1777, Martínez, Príncipe

28 Tres años separan las aprobaciones de la censura (1779) de la primera fecha de representación (compañía de Juan Ponce, 1782). Existe un recibo de 500 reales del 6 de enero de 1783 (14 $\left.016^{3}\right)$. Es raro que el sainete le haya sido pagado con tanto retraso. Podría explicar por qué entre ambas fechas (1779 y 1782), Vázquez propuso Los matuetas andaluces a la compañía de Manuel Martínez, una refundición de Ceder la novia que se estrena el 5/5/1780, y por la cual cobró 400 reales en mayo de 1780.

${ }^{29}$ No hay nada más próximo a la fecha de estreno. No sabemos por lo tanto si el sorprendente final es el original, ya que el criado se suicida de verdad.

30 Este manuscrito viene sin censura ni lugar, pero figura el reparto de 1799, y la mención «Dionisio Ibáñez» en portada, supuestamente el nombre del actor a quien pertenecía. Es un ejemplar idéntico a los de Sevilla (BHM TEA 1-212-56, A, B, C). 
BHM TEA 1-154-11 B (censuras de 1777)

5 representaciones más entre 1779 y 1800

17. Los chascos

25/12/1766, Calle, Cruz

No hay manuscrito ${ }^{31}$

Ningún rastro de otra representación

18. Chirivitas el yesero

4/10/1774, Martínez, Príncipe

BHM TEA 1-153-18 A (autógrafo)

17 representaciones más de 1777 a 1806

19. degollado fingido, El (y chascos del bodeguero)

25/12/1778, Martínez, Príncipe

BHM TEA 1-154-42 C (autógrafo)

BNM 14 520²: censuras de 1778

Ningún rastro de otra representación

20. Las delicias del Canal en barcos, merienda y bailes

21/06/ 1774, Martínez, Cruz

BHM TEA 1-183-42 B (censuras de 1774)

4 representaciones más por lo menos de 1774 a 1782

21. El día de lotería (La lotería, primera parte)

6/6/1777, Martínez, Príncipe

BHM TEA 1-154-34 B («Bazquez» y «1777» en portada)

11 representaciones más de 1778 a 1798

22. Los dos hermanos, (el) uno glotón y (el) otro sin memoria

25/12/1785, Martínez, Cruz

BHM TEA 1-154-40 B (censuras de 1785)

2 representaciones más en 1806

23. El de las manías y médicos fingidos

5/12/1774, Martínez, Príncipe

BNM $14520^{13}$ (censuras de 1774)

«su autor Don Sebastian Bazquez» en portada

4 representaciones más entre 1777 y 1790

24. Los embustes creídos; para empezar de graciosa la Vicenta Sanz

20/04/1783, Martínez, Príncipe

BHM TEA 1- 183-63 A y C

(A: censuras de 1783; C: autógrafo)

31 «A Sebastián Baz por el entremés de Los chascos que se mudó al tercer día, 300» (AMMA, 1-432-1).» (Cartelera teatral madrileña..., 1. a ed., t. II, nota 181, pág. 896). 
Ningún rastro de otra representación

25. La entrega de sainetistas

7/04/1776, Martínez, Cruz

BHM TEA 1-185-23 C y D

(C: censuras de 1776 y reparto; D: autógrafo)

Ningún rastro de otra representación

26. Escarmiento de estafadoras y desengaño de amadores

10/02/1776, Martínez, Príncipe

BHM TEA 1-155-4: el reparto corresponde a la composición de la compañía de Martínez de 1776

12 representaciones más de 1778 a 1800

27. El esquileo o los amantes descubiertos

11/06/1779, Martínez, Príncipe

BHM TEA 1-155-33 A, y C

(A: fragmentos autógrafos; C: censuras y reparto de 1779)

11 representaciones más de 1784 a 1804

28. La/El farfulla de las mujeres y jardineros graciosos

24/9/1777, Martínez, Príncipe

BHM TEA 1-155-26 C (autógrafo, aunque con censuras de 1816)

13 representaciones más de 1778 a 1799

29. El gabinete divertido de toda clase de figuras naturales

24/12/1780, Martínez, Príncipe

BNN $14602^{21}$ (autógrafo con reparto)

BHM TEA 1-155-7 B (censuras de 1780)

Ningún rastro de otra representación

30. Garrido ingenio

4/10/1774, Martínez, Príncipe

BHM TEA 1-186-12 (censuras de 1774)

Ningún rastro de otra representación

31. Los graciosos descontentos

7/05/1779, Martínez, Príncipe

BHM TEA 1-212-3732

Ningún rastro de otra representación

32. El gracioso engaño del duende fingido

25/12/1777 (¿estreno?), Martínez, Cruz

32 El estudio del reparto demuestra que es anterior a 1780, ya que Nicolás López figura en él, y se jubiló en 1780. Están también Pedro A. Galván, jubilado en 1781, Silveria de Rivas, fallecida en 1782, Granadina (María de la Chica) jubilada en 1782, etc. 
BHM TEA 1-154-37 A (autógrafo)

12 representaciones más de 1779 a 1808

33. El hambriento en Nochebuena

25/12/1774, Martínez, Príncipe

BNM $14520^{32}$ («por Don Sebastián Bazquez, año de 1774» en portada)

3 representaciones más de 1775 a 1806

34. Hasta aquí llegó el sainete, (Riña de Polonia con Chinita)

24/12/1775, Ribera, Príncipe

BHM TEA 1-183-31 («1775» en portada)

Ningún rastro de otra representación

35. Introducción jocosa para presentar a María Monteis en el teatro

15/12/1779, Ponce, Príncipe

BHM TEA 1-184-1 (Y) 1 (censuras de 1779)

Ningún rastro de otra representación

36. Lo que es del agua el agua se lo lleva (La taberna del tío Pilatos)

24/12/1775, Ribera, Príncipe

BHM TEA 1-169-7 A (autógrafo)

Ningún rastro de otra representación

37. La locura fingida y amor logrado (y boda conseguida)

18/05/1793, Martínez, Príncipe

BHM TEA 1-210-11 A y B

(A: censuras de 1793; B: autógrafo)

4 representaciones más entre 1798 y 1807

38. La locura más graciosa en obsequio del monarca

4/11/1789, Ribera, Príncipe

BHM TEA 1-166-50 B y D

(B: censuras de 1789; D: autógrafo y reparto)

Ningún rastro de otra representación

39. Las locuras más graciosas por el engaño creído

24/12/1782, Martínez, Príncipe

BHM TEA 1-156-37 A (censuras de 1782)

Ningún rastro de otra representación

40. El marido desengañado y escarmiento de mujeres

Titulado así a petición del censor. Título original: El chasco de la bebida 25/12/1792, Martínez, Príncipe

BHM TEA 1-157-25 B (autógrafo y censuras de 1792)

41. Los matuetas andaluces

5/5/1780, Martínez, Cruz

BHM TEA 1-157-12 
Ningún rastro de otra representación

Versión apenas retocada de Ceder la novia y dar dinero encima

42. La merienda desgraciada de plumistas y criados

15/7/1782, Martínez, Príncipe

BHM TEA 1-157-11 A y C

(A: censuras de 1782; C: autógrafo)

Ningún rastro de otra representación

Recibo de 400 reales de 1782

43. Míralo todo en la tarde de San Blas, (El)

¿Enero de 1778?

BHM TEA 1-157-8 A y D

(A: censuras de 26, 27 y 29 de enero de 1778; D: autógrafo. «29 en 1778» en portada)

Ningún rastro de otra representación

44. El modelo del nuevo peinado de París

6/11/1778, Martínez, Príncipe

BHM TEA 1-183-82 B y C

(B: aprobaciones de 1778; C: autógrafo)

Ningún rastro de otra representación

45. Las mujeres conjuradas (2 partes)

14/11/1774, Martínez, Príncipe

BHM TEA 1-184-54 (censuras de 1774)

Ningún rastro de otra representación

46. No hay [se halla] rato mejor que el de la Plaza Mayor

7/11/1777, Martínez, Cruz

BHM TEA 1-157-41 A y C

(A: censuras de 1777; C: autógrafo)

Ningún rastro de otra representación

47. La novia satisfecha y el novio amedrentado

2/2/1783, Martínez, Príncipe

BHM TEA 1-157-43 A y C

(A: censuras de 1783; C: autógrafo)

Ningún rastro de otra representación

48. El obrador de sastres

25/12/1778, Martínez, Príncipe

BHM TEA 1-158-6 A y C

(A: censuras de 1778; C: autógrafo)

Ningún rastro de otra representación 
49. Paca la salada y merienda de horterillas ${ }^{33}$

29/1/1790, Ribera, Príncipe

BHM TEA 1-167-30 A (censuras de 1790)

2 representaciones más en 1797 y 1798

50. El padre enfermo y la niña con amor

17/12/1781, Martínez, Cruz

BHM TEA 1-158-16 B y C

(B: autógrafo; C: censuras de 1781)

Otra representación en 1787

51. Los pasajes graciosos de un lugar

23/5/1779, Martínez, Príncipe

BHM TEA 1-158-44 C (censuras de 1779. 2 páginas autógrafas, relativas a la intervención del pallaso)

Ningún rastro de otra representación

52. Los payos de trillo (con el anteojo descúbrelo todo)

22/6/1781, Palomino, Cruz

BHM TEA 1-168-3 A (censuras de 1781)

Ningún rastro de otra representación

53. La pequeña folla

Probablemente estrenado el 16/2/1775², Martínez

BHM TEA 1-184-18 (censuras de 1775)

Ningún rastro de otra representación

54. Perico el empedrador

26/6/1787, Martínez, Príncipe

BHM TEA 1-158-10 B y C

(B: censuras de 1787; C: autógrafo)

5 representaciones más de 1787 a 1795

55. Pues que lucro no tenemos trabajando noche y días, deshagamos compañía y otro detino busquemos

13/5/1780, Martínez, Cruz

BHM TEA 1-159-1 A y D

(A: censuras de 1780; D: varias páginas autógrafas)

Ningún rastro de otra representación

Sainete también titulado La compañía desdichada, La compañía deshecha o

Los empedradores

33 El manuscrito TEA 1-167-30 B titulado «Paca la salada» («o merienda de orterillas» tachado) no tiene nada que ver con el sainete de Vázquez.

34 El manuscrito lleva las aprobaciones de 11, 12, 13, 14 y 15 de febrero, y el «represéntese» de 16 de febrero de 1775 . 
56. La quintaesencia de la miseria

7/11/1777, Martínez, Cruz

BHM TEA 1-159-18 A y C

(A: censuras de 1777; C: autógrafo)

6 representaciones más de 1783 a 1791

57. La residencia de defectos

26/5/1792, Ribera, Príncipe

BHM TEA 1-169-17 B (censuras de 1792)

Ningún rastro de otra representación

58. El retorno de Francia del viajante majadero

7/12/1782, Martínez, Príncipe

BHM TEA 1-159-24 A y D

(A: censuras de 1782; D: autógrafo)

Ningún rastro de otra representación

59. Sainete para la tonadilla de la cucaña

10/2/1776, Ribera, Príncipe

BHM TEA 1-184-1 (00)

Sin censura, pero fecha de «1776»

Ningún rastro de otra representación

60. Sainete nuevo para empezar a ser graciosa la Nicolasa (El sueño)

31/3/1782, Martínez, Cruz

BHM TEA 1-184-21 C (censuras de 1782)

Otra representación en 1789

61. Sainete para presentar al público de Madrid a la señora Mariana Márquez, en la primera semana de la temporada de las representaciones de por la noche 1/7/1794, Martínez, Príncipe

BHM TEA 1-158-36 A (censuras de 1794)

Ningún rastro de otra representación

62. El señorito enamorado

Se tiene noticia de este sainete por primera vez en la temporada (1776-1777),

Ribera

BHM TEA 1-169-43 B (autógrafo)

2 representaciones más en 1779 y 1787

63. La soberbia castigada y la clemencia premiada (El zapatero y la baronesa)

3/6/ 1782, Martínez, Cruz

BHM TEA 1-159-32 C y E

(C: censuras de 1781; E: autógrafo)

Ningún rastro de otra representación

64. El soplo del contrabando 
¿Vázquez?

30/1/1775, Martínez, Príncipe

BHM TEA 1-159-44 (censuras de 1775)

Ningún rastro de otra representación

65. El $l^{35}$ sorteo de los milicianos

25/12/1774, Martínez, Príncipe

BHM TEA 1-159-37 A (censuras de 1774)

6 representaciones más entre 1787 y 1808

66. La tarde en el Prado

9/12/1798, Ramos, Príncipe

BHM TEA 1-160-8 B (autógrafo y censuras de 1798)

Ningún rastro de otra representación

67. El teatro renacido (segunda parte de Ya llegó el tiempo preciso en que nuestro curso se acabe que finalizó la temporada anterior)

23/4/1779, Martínez, Príncipe

BHM TEA 1-183-3 D (censuras de 1779)

Ningún rastro de otra representación

68. El tío Vigornia (el herrador)

7/12/1785, Martínez, Cruz

BHM TEA 1-160-22 (Impreso, Madrid, 1792, Librería de Quiroga. Notas y reparto)

10 representaciones más de 1787 a 1807

69. El torero caballero de Olmedo

Primera noticia del sainete el 14/ 2/1792, Martínez, Cruz

BHM TEA 1-160-14 B (Censuras de 1791)

Otra representación en 1800

70. El tramposo

¿Vázquez?

30/1/1775, Martínez, Príncipe

BHM TEA 1-132-8 (censuras de 1775)

21 representaciones más de 1777 a 1807

71. Las transformaciones graciosas del sopista Cubilete (o El sopista Cubilete) 25/12/1781, Palomino, Príncipe

BHM TEA 1-170-10 C (censuras de 1781). Manuscrito confuso

Otra representación en 1799

\footnotetext{
35 El sorteo de los milicianos y voluntarios de dragones es una versión muy retocada del anterior. El principio es similar (diálogos y personajes), pero el sorteo ha sido sustituido (aunque figure todavía en el título) por un bando que dice que se reclutará a cualquiera que sea visto en brazos de una mujer.
} 
72. Las travesuras de un barbero

13/7/1789, Ribera, Príncipe

BHM TEA 1-208-99 (impreso, Madrid, 1800)

73. Los tres novios imperfectos

7/12/1775, Martínez, Cruz

BHM impresos:

TEA 1-208-35 y 36 (Madrid, 1791)

TEA 1-160-17 (Madrid, 1791)

16 representaciones más de 1778 a 1807

74. El trueque de las criadas

23/05/1779, Martínez, Príncipe

BHM TEA 1-160-21 B (censuras de 1779)

9 representaciones más de 1780 a 1795

75. Un criado ser dos al mismo tiempo (a un tiempo), 2 partes, o Dos piezas de un pensamiento

5/12/1777, Martínez, Cruz

TEA 1-154-3 C y D

(C: censuras de 1777; D: autógrafo)

Ningún rastro de otra representación

Recibo de 2500 reales por la comedia Carlos Quinto sobre Viena y los sainetes

76. Los volatines fingidos

6/2/1779, Martínez, Príncipe

BHM TEA 1-152-43 A (autógrafo)

Ningún rastro de otra representación

Recibo de 1500 reales por dos sainetes y la compostura de la comedia de Giges

77. La vuelta del arriero y boda fingida

25/5/1776, Martínez, Cruz

BNM 14.520 ${ }^{21}$ (censuras de 1776)

20 representaciones más entre 1778 y 1807

78. Ya es gremio las majas

Temporada 1775-76, Martínez

BHM TEA 1-156-20 A у B

(A: autógrafo; B: censuras de 1775)

Ningún rastro de otra representación

79. Ya llegó el tiempo preciso (en que nuestro curso acabe)

6/2/1779, Martínez, Príncipe

BHM TEA 1-183-80 A у B

(A: censuras de 1779; B: autógrafo)

Otra representación en 1782 